\title{
RELIABILITY OF BONE GELATIN AMS DATING: RATTUS EXULANS AND MARINE SHELL RADIOCARBON DATES FROM PAUATAHANUI MIDDEN SITES IN WELLINGTON, NEW ZEALAND
}

\author{
Nancy Beavan Athfield ${ }^{1} \cdot$ Bruce McFadgen $^{2} \cdot$ Rodger Sparks $^{1}$
}

\begin{abstract}
A suite of 6 bone gelatin accelerator mass spectrometry (AMS) radiocarbon dates for Rattus exulans Peale and associated beta decay ${ }^{14} \mathrm{C}$ dates for Austrovenus stutchburyi shell are presented for 4 middens at Pauatahanui, Wellington, New Zealand. Mean calibrated age ranges of Rattus exulans (520-435 BP and 350-330 BP at 95\% confidence level) and shell (465-375 BP at 95\% confidence level) from the 4 midden sites overlap. The agreement between Rattus exulans bone gelatin dates and associated shell provides an inter-sample comparison of ${ }^{14} \mathrm{C}$ dating using both gas counting (beta decay) and AMS dating techniques. We examine the adequacy of the standard gelatinization treatment for bone samples, which has been employed consistently at the laboratory since 1995 .
\end{abstract}

\section{INTRODUCTION}

Bones of some Rattus exulans found in naturally deposited, avian predator middens in New Zealand have conventional radiocarbon ages up to $2 \mathrm{ka}$ BP (Holdaway 1996). These ages are considerably older than the accepted timing for the human colonization of New Zealand of less than around 700 BP, based on analyses of ${ }^{14} \mathrm{C}$ dates for human occupation sites (Anderson 1991; McFadgen et al. 1994; Higham and Hogg 1997). Rattus exulans is not endemic to New Zealand. Its arrival on Pacific islands is associated only with transport by humans (Matissoo-Smith 1994) and ${ }^{14} \mathrm{C}$ ages on subfossil specimens of Rattus exulans are thus a proxy for the times of earliest human contact with New Zealand.

An early date for the colonization of New Zealand by Rattus exulans has implications for understanding changes in New Zealand's unique biodiversity following human contact. It is therefore important to determine whether the date of about $2 \mathrm{ka} \mathrm{BP}$ for the arrival of Rattus exulans is reliable.

There has been some controversy as to the reliability of the earliest dates of 1500-2000 BP for Rattus exulans from avian predator sites. It has been suggested that the anomalous Rattus exulans ages are a dietary effect arising from rodents eating marine-based foods depleted in ${ }^{14} \mathrm{C}$ (Anderson 1996). Beavan and Sparks (1998) have reviewed modern, island-based populations of Rattus exulans and observed small variations of ${ }^{14} \mathrm{C}$ that could be associated with diet. The partitioning of diet between marine and terrestrial sources of food, however, appears to moderate the full effect of a marine depletion, and depletions seen in modern populations of Rattus exulans suggest that the effect on ${ }^{14} \mathrm{C}$ ages would be $<300{ }^{14} \mathrm{C}$ yr. This is considerably less than required to explain the $800-1200$-yr shift from approximately $700 \mathrm{BP}$ in the oldest Rattus exulans dates from the natural sites, as in Holdaway's (1996) corpus of samples.

Anderson (1996) has also criticized the efficacy of the preparation methods used in obtaining Rattus exulans ages. At one occupation site, Pleasant River in North Otago, New Zealand, results from 2 laboratories, including Rafter, have Rattus exulans with calibrated ages up to $900 \mathrm{yr}$ greater than the $400-800 \mathrm{cal}$ BP time span of midden layers as based on ${ }^{14} \mathrm{C}$ dates of associated shells and charcoals (Smith and Anderson 1998). The Rafter Lab examined soils from the site for significantly depleted carbon that could exchange with bone, yet found no obvious source of a tenacious contaminant. Work on the problem at this cultural site at Pleasant River will be described in a separate publication

${ }^{1}$ Rafter Radiocarbon Laboratory, Institute of Geological and Nuclear Sciences, Lower Hutt, New Zealand

${ }^{2}$ New Zealand Department of Conservation, Science and Research Unit, PO Box 10420, Wellington, New Zealand 
(Beavan and Smith forthcoming). In addition, a review of the reliability of bone gelatin dates from $\mathrm{CaCO}_{3}$-rich deposits in predator-deposited sites has been completed (Holdaway and Beavan 1999).

In this paper we report on other tests of the efficacy of chemical preparation techniques employed at the Rafter Laboratory and used for all rat bone since 1995. We have used Rattus exulans mandibles from middens of known age on the southern shore of the Pauatahanui Harbor, north of Wellington, New Zealand (Figures 1 and 2). We compare the results to ${ }^{14} \mathrm{C}$ dates on marine shells from the same middens. We also utilize a protocol for detecting the exchange of carbon between bones and their burial environment via amino acid and isotopic analysis of both bones and burial soils.

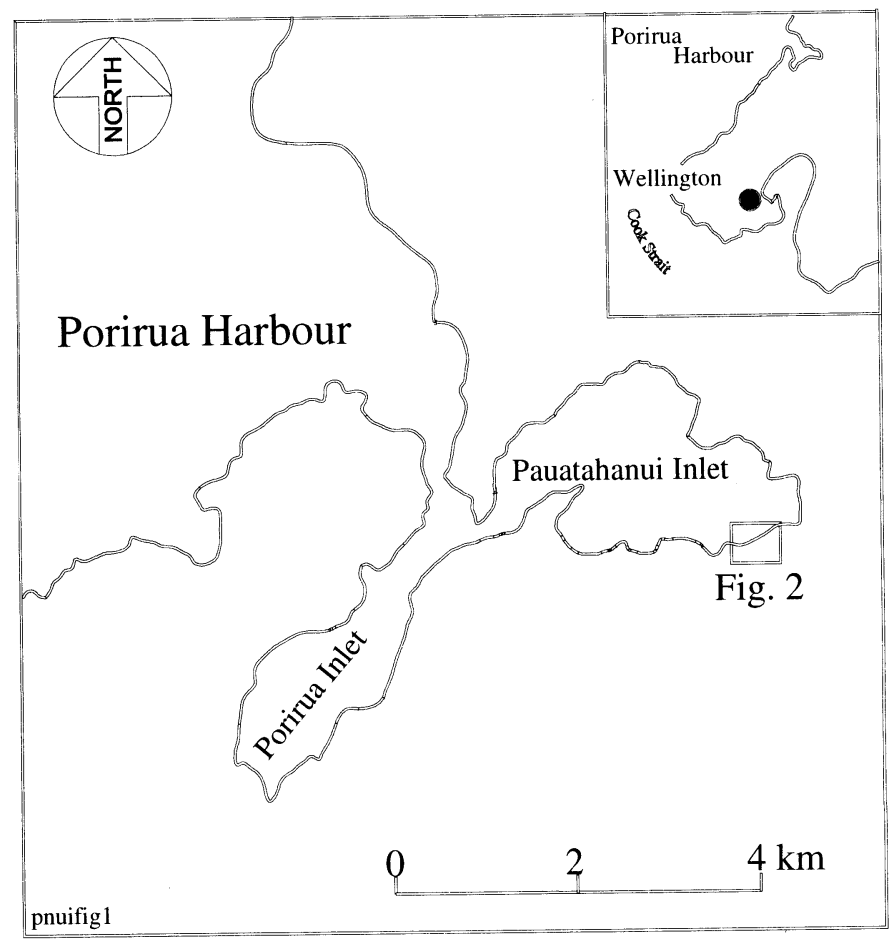

Figure 1 Location of Pauatahanui Inlet

\section{Pauatahanui Middens}

Pauatahanui Harbour is an inland arm of the sea that formed when a river valley was drowned by the rise in sea level at the end of the last Pleistocene glaciation (Figure 1). Hills around the harbor are greywacke sandstone mantled by non-calcareous loess deposited during the Pleistocene glaciations (Healy 1980). Shell middens on the shoreline and hills around the harbor mark the sites of old cultivation grounds and temporary hunting and gathering camps used by the Maori in prehistoric times.

The 4 shell middens (M1, M2, M4, site R27/45; M9, site R27/35) on hills behind the southeastern shore of the harbor (Figure 2) were excavated in 1978-1979. The middens were discrete deposits of shells originally discarded on the ground surface, covering an area between approximately $60 \mathrm{~m}^{2}$ and $225 \mathrm{~m}^{2}$. The maximum thicknesses of the deposits varied between the 4 middens from 10 to $35 \mathrm{~cm}$. Over time, the shells gradually became incorporated into the topsoil. At the midden edges, where shell layers were thin, the shells had been scattered through the topsoil by soil biological activity. On the thicker parts of the middens, windblown drift had buried the shells and gradually 
percolated down through them. Soil-forming processes had not entirely destroyed the stratigraphy, and a few shell lenses comprising concentrations of burnt shell and various-sized shell could be discerned. Apart from the few shell lenses, there were no other stratigraphic breaks.

All 4 middens contained the bones of Rattus exulans that had been hunted and trapped in the surrounding forest and grassland. The bones were stained and blackened by contact with the burial soil. Soils formed of greywacke and loess are typically moderately acid (NZ Soil Bureau 1968), which would contribute to the weathering of the bone. The preservation of the Rattus exulans bones within the middens was aided by the calcareous nature of the associated shell.

The shells from the middens (M1, M2, M4, M9, Figure 2) were ${ }^{14} \mathrm{C}$-dated by the gas-counting (beta decay) method in 1979 (R A Empson and B G McFadgen, unpublished data). ${ }^{14} \mathrm{C}$ dates for shells of the harbor bivalve Austrovenus stutchburyi (M1, M2, M4, M9) and the ocean coast, rocky shore gastropod Haliotis iris (M1) indicate that the middens were deposited between 375 and 465 cal BP (see Table 3). Archived samples of Rattus exulans jawbones from each of the 4 middens were submitted for ${ }^{14} \mathrm{C}$ analysis by AMS in 1997.

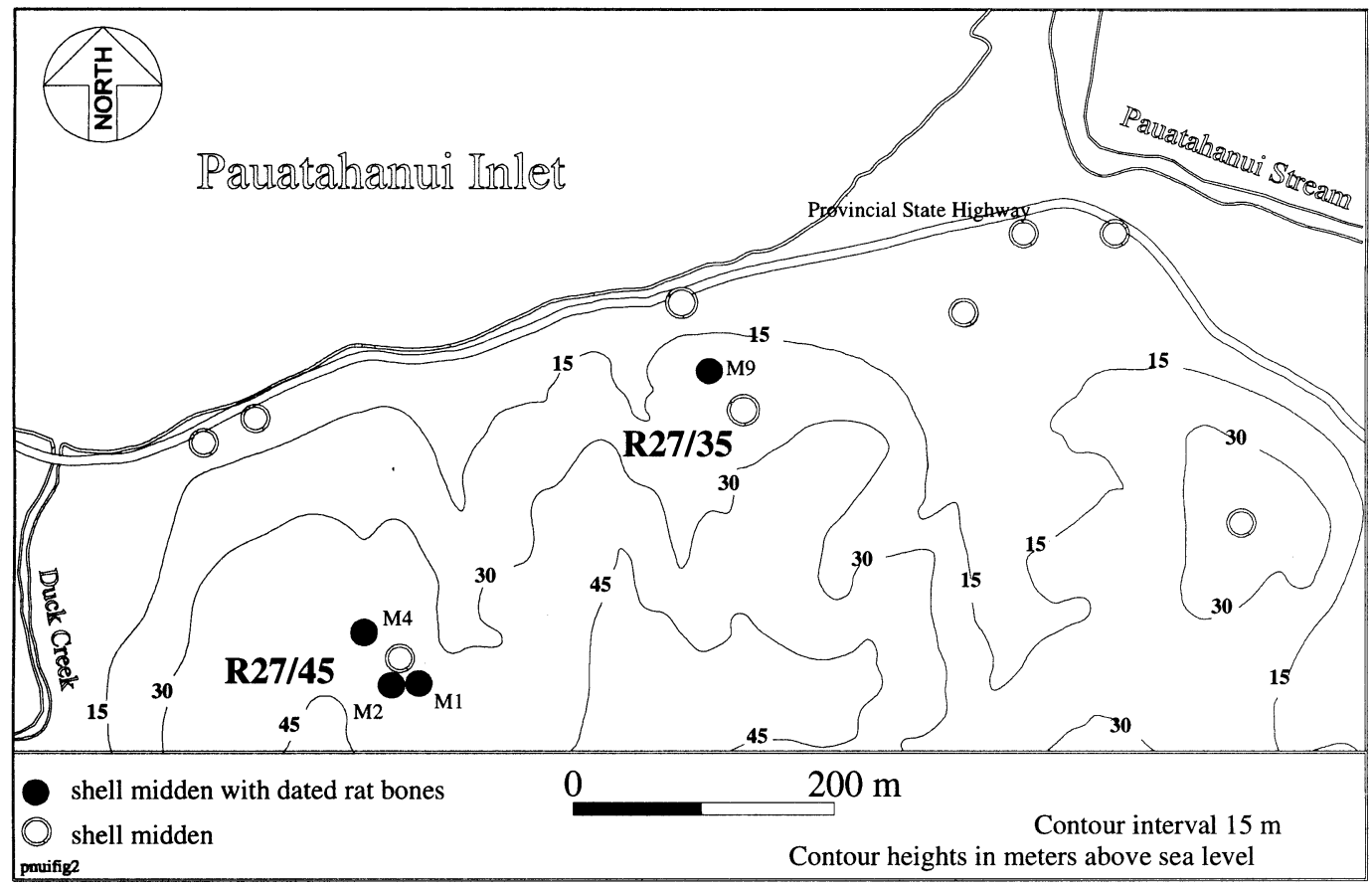

Figure 2 Locations of Pauatahanui shell middens with dated Rattus exulans bones

\section{Laboratory Procedures}

\section{Rattus exulans Bone Samples}

Jaw bones were brushed to remove burial soil, washed and sonically cleaned in deionized water, and dried in a vacuum oven at $30^{\circ} \mathrm{C}$. Each sample was pulverized in mortar and pestle to $<450 \mu \mathrm{m}$, and demineralized in $0.5 \mathrm{M} \mathrm{HCl}$ while stirring at room temperature for $1 \mathrm{~h}$. Collagen was filtered from the solution and gelatinized with $0.01 \mathrm{M} \mathrm{HCl}$ in a nitrogen atmosphere at $90^{\circ} \mathrm{C}$ for $16 \mathrm{~h}$. The gelatin was double-filtered through Whatman ${ }^{\circledR} \mathrm{GF} / \mathrm{C}$ and $0.45 \mu \mathrm{m}$ Acrodisc ${ }^{\circledR}$ filters, and lyophilized to 
determine yields. An average of $4 \mathrm{mg}$ of bone gelatin was combusted in sealed tubes with $\mathrm{CuO}$ and silver wire at $900{ }^{\circ} \mathrm{C}$. The $\mathrm{CO}_{2}$ from the combustions was graphitized and analyzed by AMS after an aliquot had been taken for $\delta^{13} \mathrm{C}$ analysis.

\section{Shell Samples}

The shells were dated by conventional (gas counting) methods in 1979. X-ray diffraction showed between $0.65 \%$ and $0.25 \%$ calcite. Between 109 and $122 \mathrm{~g}$ of crushed shell was treated with $400 \mathrm{~mL}$ concentrated $\mathrm{HCl}$. After drying, the evolved gas was purified by absorption in $\mathrm{CaO}$ at $500{ }^{\circ} \mathrm{C}$ and reevolved by heating the resulting carbonate to $800-900^{\circ} \mathrm{C}$. The $\mathrm{CO}_{2}$ from each sample was stored for up to 3 weeks before counting to allow radon to decay.

\section{Soil Samples}

A $1.87 \mathrm{~g}$ sample of soil that was clinging to bones from Midden 4 (R27/45) was picked free of root hairs and shell fragments, sieved to $<212 \mu \mathrm{m}$, and ground in a mortar and pestle. The soil was washed twice in $0.5 \mathrm{M} \mathrm{HCl}$ at $85^{\circ} \mathrm{C}$ for $30 \mathrm{~min}$ to remove carbonates, then filtered and rinsed to neutrality. Residue and final wash solution were lyophilized, for a yield of $1.495 \mathrm{~g}$. A $104.1 \mathrm{mg}$ sample of this prepared soil was combusted as above yielding $4.0 \mathrm{mg}$ of carbon, which was graphitized for AMS analysis of total organic carbon of the soil.

We then prepared an extract of free amino acids from the total organic carbon component of the soil with $5 \mathrm{M} \mathrm{HCl}$. The mixture was placed in a Pyre ${ }^{\circledR}$ tube and sealed under nitrogen, then heated at $100{ }^{\circ} \mathrm{C}$ for $16 \mathrm{~h}$. The extract was double-filtered through Whatman ${ }^{\circledR} \mathrm{GF} / \mathrm{C}$ and $0.45 \mu \mathrm{m}$ Acrodisc ${ }^{\circledR}$ filters, and lyophilized to determine yields.

\section{Amino Acid Analysis}

Subsamples of $1 \mathrm{mg}$ of hydrolyzed bone protein, and a sample of the amino extract from Midden 4 soil, were analyzed on a Waters Pico-Tag HPLC system by the Renal Research Unit of Wellington School of Medicine using the method of Negro et al. (1987).

\section{Stable Isotope Analysis}

Carbon and nitrogen in the samples were analyzed by an ANCA-SL elemental analyzer in continuous-flow mode interfaced to a Europa Scientific Geo 20/20 mass spectrometer. Carbon and nitrogen isotopes were analyzed simultaneously from an average $1.5 \mathrm{mg}$ of sample. $\mathrm{The}^{\mathrm{CO}} \mathrm{CO}_{2}$ and nitrogen gases were resolved using chromatographic separation on a GC column at $85^{\circ} \mathrm{C}$, and analyzed for $\delta^{13} \mathrm{C}$ and $\delta^{15} \mathrm{~N}$ and $\mathrm{C} / \mathrm{N}$ ratios. Machine error values are $\pm 0.1 \%$ for carbon and $\pm 0.3 \%$ or better for nitrogen.

\section{RESULTS}

\section{Rattus exulans Bone Condition}

The amino acid composition of bone protein was examined to detect protein degradation or intrusion of free amino acid from soils, in the manner of Stafford et al. (1988). The amino acid profile of the Pauatahanui bones is compared to a Sigma ${ }^{\circledR}$ rat tail Type 1 collagen and the average of 9 amino-acid profiles from modern populations of Rattus exulans (Table 1).

The amino-acid profiles of the Pauatahanui subfossil bones are in good agreement with the modern rat protein standards, and indicate minimal diagenetic change to the former. There is also no evi- 
dence of exogenous amino acid contamination in the purified protein when the Pauatahanui bones are compared to the profile of free amino acids in the burial soil.

The Pauatahanui bones have stable isotope values (Table 2) within the expected range for terrestrialbased diet (DeNiro and Epstein 1978, 1981; DeNiro 1985). In addition, the C/N ratios for Pauatahanui bone protein (Table 2) are within the 2.9-3.6 range for well-preserved bone (DeNiro 1985).

Table 1 Amino acid values (residues/1000) from amino-acid profiles for Pauatahanui Rattus exulans and soil of burial compared with Sigma ${ }^{\circledR}$ rat tail standard and modern R. exulans bones

\begin{tabular}{|c|c|c|c|c|}
\hline Amino acid & $\begin{array}{l}\text { Sigma }^{\circledR} \text { rat } \\
\text { standard }^{\mathrm{a}}\end{array}$ & $\begin{array}{c}\text { Modern Rattus exulans } \\
\text { average }^{\mathrm{b}}\end{array}$ & $\begin{array}{c}\text { Pauatahanui Rattus } \\
\text { exulans average }\end{array}$ & $\begin{array}{l}\mathrm{R} 21565 / 1 \\
\text { soil }\end{array}$ \\
\hline Hydroxyproline & 74.0 & $83.1 \pm 3.4$ & $91.4 \pm 3.5$ & 10.0 \\
\hline Aspartic & 47.8 & $47.0 \pm 2.4$ & $51.5 \pm 6.0$ & 320.1 \\
\hline Glutamine & 76.5 & $81.0 \pm 3.4$ & $84.7 \pm 6.6$ & 96.8 \\
\hline Proline & 112.4 & $111.0 \pm 2.5$ & $118.0 \pm 4.0$ & 54.2 \\
\hline Glycine & 300.0 & $310.0 \pm 8.2$ & $318.0 \pm 13.4$ & 156.1 \\
\hline Alanine & 117.4 & $107.0 \pm 2.2$ & $115.5 \pm 3.6$ & 94.4 \\
\hline Arginine & 49.1 & $49.9 \pm 0.6$ & $47.5 \pm 0.3$ & 8.4 \\
\hline
\end{tabular}

${ }^{\text {aSigma }}{ }^{\circledR}$ Rattus Type 1 collagen standard, Lot $36 \mathrm{H} 3873$

${ }^{\mathrm{b}}$ Average of 9 modern Rattus exulans from Kapiti Island, Wellington, New Zealand. From Beavan and Sparks (1998).

cAverage of 6 Pauatahanui Rattus exulans samples, R21565/1,2,4,7,8,9

Table $2 \mathrm{C} / \mathrm{N}$ ratios and stable isotope data for Rattus exulans bones from Pauatahanui

\begin{tabular}{llcrccc}
\hline Sample ID & $\begin{array}{l}\text { Archaeological } \\
\text { site nr }\end{array}$ & $\begin{array}{l}\delta^{15} \mathrm{~N} \\
(\% o)\end{array}$ & $\% \mathrm{~N}$ & $\begin{array}{l}\delta^{13} \mathrm{C} \\
(\%)\end{array}$ & $\% \mathrm{C}$ & $\mathrm{C} / \mathrm{N}$ \\
\hline $\mathrm{R} 21565 / 1$ & $\mathrm{R} 27 / 45$ (M4) & 8.3 & 15.2 & -20.6 & 49.7 & 3.3 \\
$\mathrm{R} 21565 / 2$ & $\mathrm{R} 27 / 45$ (M1) & 8.1 & 6.8 & -20.2 & 21.2 & 3.1 \\
$\mathrm{R} 21565 / 4$ & $\mathrm{R} 27 / 35$ (M9) & 5.5 & 10.2 & -20.9 & 32.7 & 3.2 \\
$\mathrm{R} 21565 / 7$ & $\mathrm{R} 27 / 35$ (M9) & 6.9 & 14.6 & -19.6 & 43.1 & 2.9 \\
$\mathrm{R} 21565 / 8$ & $\mathrm{R} 27 / 45$ (M2) & 9.9 & 13.7 & -20.2 & 40.5 & 2.9 \\
$\mathrm{R} 21565 / 9$ & $\mathrm{R} 27 / 35$ (M9) & 9.3 & 11.9 & -19.3 & 34.9 & 2.9 \\
\hline
\end{tabular}

\section{Comparison of Rat Dates and Shell Dates}

The ages of the rat bones are compared to the shell ages in Table 3. There is no a priori reason to expect the shell middens to all be contemporary; nevertheless the shell dates are not significantly different $\left(\mathrm{T}^{\prime}\left(\right.\right.$ Ward and Wilson 1978) $=4.7, \mathrm{~T}_{0.95, \mathrm{df}=5}^{\prime}=7.81$ ). Because the shells are marine organisms and rats are terrestrial, their ${ }^{14} \mathrm{C}$ ages are not directly comparable. However, if the rats are contemporary with the middens, the rat ${ }^{14} \mathrm{C}$ ages should be a homogenous set and the calibrated mean ages of the shells and bones should overlap. Comparison of the rat dates shows that they are not sig-

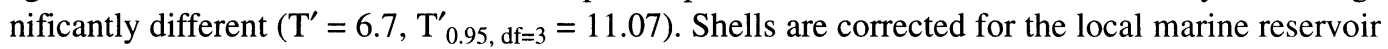
effect by applying a $\Delta \mathrm{R}$ correction of $-30 \pm 15$ (McFadgen and Manning 1990). Calibration of the weighted means of each date set shows that their $95 \%$ confidence limits age ranges overlap by $30 \mathrm{yr}$.

\section{Soil Organic Carbon}

We examined the possibility that a soluble component of soil organic carbon, either humic acids or free amino acids from soil humics, could be incorporated into the bone. Free amino acids are formed by the degradation of soil organic matter, and are incorporated in mobile soil humic acids. If the soil 
Table 3 Radiocarbon ages for rat bones and marine shells from Pauatahanui archaeological sites ${ }^{\mathrm{a}}$

\begin{tabular}{|c|c|c|c|c|}
\hline \multirow[b]{2}{*}{ Archaeological site $\mathrm{nr}$} & \multicolumn{2}{|c|}{ Rattus exulans } & \multicolumn{2}{|c|}{ Austrovenus stutchburyi } \\
\hline & CRA & Lab nr & $\begin{array}{l}\text { CRA with marine- } \\
\text { calibrated age range }\end{array}$ & Lab nr \\
\hline $\mathrm{R} 27 / 45$ (M1) & $422 \pm 84$ & NZA7932 & $\begin{array}{c}833 \pm 67 \\
630-415 \mathrm{BP}\end{array}$ & NZ4699 \\
\hline $\mathrm{R} 27 / 45$ (M2) & $452 \pm 69$ & NZA7411 & $\begin{array}{c}722 \pm 28 \\
450-310 \mathrm{BP}\end{array}$ & NZ4859 \\
\hline $\mathrm{R} 27 / 45$ (M4) & $361 \pm 68$ & NZA7044 & $\begin{array}{c}797 \pm 33 \\
510-395 \mathrm{BP}\end{array}$ & NZ4861 \\
\hline $\begin{array}{l}\text { R27/35(M9) } \\
\text { R27/35 (M9) } \\
\text { R27/35 (M9) }\end{array}$ & $\begin{array}{l}439 \pm 71 \\
548 \pm 68 \\
313 \pm 68\end{array}$ & $\begin{array}{l}\text { NZA7410 } \\
\text { NZA7933 } \\
\text { NZA7934 }\end{array}$ & $\begin{array}{c}736 \pm 28 \\
460-315 \mathrm{BP}\end{array}$ & NZ4855 \\
\hline Weighted means of CRAs & $\begin{array}{c}422 \pm 30 \\
\mathrm{~T}^{\prime}=6.7, \mathrm{df}=5\end{array}$ & & $\begin{array}{c}752 \pm 17 \\
\mathrm{~T}^{\prime}=4.7, \mathrm{df}=3\end{array}$ & \\
\hline $\begin{array}{l}\text { Calibrated age range of } \\
\text { weighted means }\end{array}$ & $\begin{array}{l}520-435 \\
350-330 \\
\mathrm{BP}(95 \%)\end{array}$ & & 465-375 BP (95\%) & \\
\hline
\end{tabular}

aMarine ${ }^{14} \mathrm{C}$ calibrations according to Stuiver and Braziunas (1993), with $\Delta \mathrm{R}=-30 \pm 15$ (McFadgen and Manning 1990). Weighted means of conventional radiocarbon ages (CRA) and T' statistic according to Ward and Wilson (1978) (T' 0.95 , df $=5=11.07, \mathrm{~T}^{\prime} 0.95, \mathrm{df}=3=7.81$.) Terrestrial ${ }^{14} \mathrm{C}$ decadal calibrations according Stuiver and Pearson (1993) with no hemisphere offset.

amino acids were contaminating the Rattus exulans bone protein, we might then expect an alteration of bone amino acid profile or an age for the bones which was different from the shells. To test for effects of burial environment on bone dates, we analyzed prepared soil and the extracted soil amino acids from Midden 4 burial soil for stable isotopes, determined the ${ }^{14} \mathrm{C}$ ages of the fractions, and made a soil-extract amino acid profile.

The total organic carbon component of the burial soil from around Rattus exulans samples from Midden 4 (R27/45) had a $\delta^{13} \mathrm{C}$ of $-27 \%$ (Table 4). Two targets made from the total organic carbon component returned conventional ${ }^{14} \mathrm{C}$ ages of $386 \pm 69 \mathrm{BP}$ and $491 \pm 69 \mathrm{BP}$ (Table 4).

We then carried out the extraction of free amino acids from the total organic carbon component. The yield of amino acid extract from the total organic carbon component was less than $1 \%$, and when combusted, yielded approximately $16 \%$ carbon.

The age for the soil free amino acid extract ( $47 \pm 67 \mathrm{yr}, \mathrm{NZA}-8357)$ is less than the conventional radiocarbon age (CRA) of the Rattus exulans bones from Midden 4 (361 $\pm 68 \mathrm{yr}$, NZA-7044), and the insoluble residue of the soil after the amino acid extraction ( $675 \pm 70 \mathrm{yr}$, NZA-8356) is greater (Table 4). While the soil amino acid shows a significantly younger ${ }^{14} \mathrm{C}$ age than the bone, other evidence indicates that exogenous amino acids are unlikely to be affecting data derived from rat bone protein. The amino acid analysis of the soil extract has a noncollagenous profile (Table 1) which, when compared with the collagenous amino acid profile for the Pauatahanui Rattus exulans bones, indicates that free amino acids from the soil have not been incorporated into the bone protein. The amino acid extract of the soil has a $\delta^{13} \mathrm{C}$ of $-24.0 \%$ (Table 4 ), and the insoluble residue of the soil remaining after the hot-water extraction has a $\delta^{13} \mathrm{C}$ of $-26.6 \%$ (Table 4). Rattus exulans samples from all 4 middens have $\delta^{13} \mathrm{C}$ ranging from $-19.3 \%$ to $-20.9 \%$ (Table 2), indicating that the gelatinization process used in preparation of the Rattus exulans bones has removed soil contaminants. 
Table 4 Stable isotope and AMS data for Rattus exulans bones from Pauatahanui, Midden 4, compared with components of the soil of burial

\begin{tabular}{lcccl} 
Material & $\delta^{13} \mathrm{C} \%$ & $\delta^{15} \mathrm{~N} \%$ & $\mathrm{CRA}(95 \%)$ & Lab nr \\
\hline $\begin{array}{l}\text { Rattus exulans bone } \\
\text { R27/45 Midden 4 }\end{array}$ & -20.2 & 8.33 & $361 \pm 68$ & NZA-7044 \\
Soil (total organic carbon) & -27.0 & No data & $386 \pm 69$ & NZA-7036 \\
& & & $491 \pm 69$ & \\
Amino acid extract of soil & -24.0 & 7.12 & $47 \pm 67$ & NZA-8357 \\
$\begin{array}{l}\text { Insoluble soil residue, after amino } \\
\text { acid extractions }\end{array}$ & -26.6 & No data & $675 \pm 70$ & NZA-8356 \\
\hline
\end{tabular}

\section{CONCLUSION}

Bone has long been seen as difficult to date. From the Rafter Laboratory's experience of dating over 70 Rattus exulans specimens from New Zealand and elsewhere in the Pacific, and some hundreds of other bone samples, we find that the confidence in ages returned for this material can be improved by employing analytical techniques to test for degradation and contamination.

Comparison of AMS dates for Rattus exulans bone and shell from the Pauatahanui middens is a typical method of crossdating associated materials to establish confidence in ${ }^{14} \mathrm{C}$ ages returned for a particular site or specific level in a site. Holdaway (1996), for example, used the method to test the reliability of dates from a number of sites in the North and South Islands, most notably the agreement of associated bird bone, charcoal, and moa eggshell AMS dates in sequences bounded by the Taupo Pumice at Hukanui in Hawkes Bay.

In the Pauatahanui Rattus exulans samples, a standard Rafter Laboratory procedure has returned accurate ages for bone from an archaeological site, with respect to site stratigraphy and ${ }^{14} \mathrm{C}$ ages for associated shell. We have also employed a combination of amino acid profiling and stable isotope analysis $\left({ }^{15} \mathrm{~N},{ }^{13} \mathrm{C}\right)$ to evaluate possible burial contamination effects and the quality of the bone sample. The results presented here support the efficacy of a standard treatment employed at the lab since 1995, with typical agreement for bone and stratigraphically associated materials processed at the Rafter Laboratory, including the corpus of Rattus exulans and associated bone, charcoal, and eggshell dates from avian predator sites, as produced for Holdaway (1996).

\section{ACKNOWLEDGMENTS}

We would like to thank Dr Nick Greenhill, Wellington School of Medicine, for work on the amino analysis, and Dr Christine Prior for discussions involving bone dating and amino acid analysis. This research was supported by the Institute of Geological and Nuclear Sciences, Ltd, Non-Specific Output Funding (NSOF).

\section{REFERENCES}

Anderson AJ. 1991. The chronology of colonisation in New Zealand. Antiquity 65:767-95.

Anderson AJ. 1996. Was Rattus exulans in New Zealand 2000 years ago? AMS radiocarbon ages from Shag River Mouth. Archaeology in Oceania 31:178-84.

Beavan NR, Sparks RJ. 1998. Factors influencing ${ }^{14} \mathrm{C}$ ages of the Pacific rat Rattus exulans. Radiocarbon

40(2):601-13.

Beavan NR, Smith IWG. Radiocarbon dates from Rattus exulans: Further analysis of the Pleasant River case. Forthcoming.

DeNiro MJ. 1985. Postmortem preservation and alteration of in vivo bone collagen isotope ratios in relation to paleodietary reconstruction. Nature 317:806-9. 
DeNiro MJ, Epstein S. 1978. Influence of diet on the distribution of carbon isotopes in animals. Geochimica et Cosmochimica Acta 42:495-506.

DeNiro MJ, Epstein S. 1981. Influence of diet on the distribution of nitrogen isotopes in animals. Geochimica et Cosmochimica Acta 45:341-51.

Healy WB. 1980. Pauatahanui Inlet - an environmental study. New Zealand Department of Scientific and Industrial Research. DSIR Information Series 141.

Higham TFG, Hogg AG. 1997. Evidence for late Polynesian colonization of New Zealand: University of Waikato radiocarbon measurements. Radiocarbon 39(2):149-92.

Holdaway RN. 1996. The arrival of rats in New Zealand. Nature 384:225-6.

Holdaway RN, Beavan, NR. 1999. Reliable ${ }^{14} \mathrm{C}$ AMS dates on bird and Pacific rat Rattus exulans bone gelatin from a $\mathrm{CaCO}_{3}$-rich deposit. Journal of the Royal Society of New Zealand. Forthcoming.

McFadgen BG, Knox FB, Cole TRL. 1994. Radiocarbon calibration curve variations and their implications for the interpretation of New Zealand prehistory. Radiocarbon 36(2):221-36

McFadgen BG, Manning MR. 1990. Calibrating New Zealand radiocarbon dates of marine shells. Radiocarbon 32(2):229-32.

Matissoo-Smith E. 1994. The human colonisation of
Polynesia. a novel approach: genetic analysis of the Rattus exulans. Journal of the Polynesian Society 103:75-87.

New Zealand Soil Bureau. 1968. Soils of New Zealand. Part 3. NZ Soil Bureau Bulletin 26(3).

Negro A, Garbisa S, Gotte L, Spina M. 1987. The use of reversed phase high performance liquid chromatography and precolumn derivitization with dansyl chloride for quantification of specific amino acids in collagen and elastin. Analytical Biochemistry 160:39-46.

Smith IWG, Anderson AJ. 1998. Radiocarbon dates from archaeological rat bone: the Pleasant River case. Archaeology in Oceania 33:88-91.

Stafford TW, Brendel K, Duhamel RC. 1988. Radiocarbon, ${ }^{13} \mathrm{C}$ and ${ }^{15} \mathrm{~N}$ analysis of fossil bone: removal of humates with XAD-2 resin. Geochimica et Cosmo chimica Acta 52:2257-67.

Stuiver M, Braziunas TF. 1993. Modelling atmospheric ${ }^{14} \mathrm{C}$ influences and ${ }^{14} \mathrm{C}$ ages of marine samples to 10,000 BC. Radiocarbon 35(1):137-89.

Stuiver M, Pearson GW. 1993. High-precision bidecadal calibration of the radiocarbon time scale, AD 1950500 BC and 2500-6000 BC. Radiocarbon 35(1):1-24.

Ward GK, Wilson SR. 1978. Procedures for comparing and combining radiocarbon age determinations: a critique. Archaeometry 20(1):19-31. 